Check for updates

Cite this: RSC Chem. Biol., 2021, 2, 1144

Received 25th March 2021 Accepted 1st June 2021

DOI: 10.1039/d1cb00063b

rsc.li/rsc-chembio

\title{
Wnt signaling activation: targets and therapeutic opportunities for stem cell therapy and regenerative medicine
}

\author{
Clémence Bonnet, (D) ${ }^{\mathrm{ab}}$ Anvi Brahmbhatt, ${ }^{a}$ Sophie X. Deng ${ }^{\mathrm{ac}}$ and Jie J. Zheng ${ }^{\text {ac }}$
}

\begin{abstract}
Wnt proteins are secreted morphogens that play critical roles in embryonic development, stem cell proliferation, self-renewal, tissue regeneration and remodeling in adults. While aberrant Wnt signaling contributes to diseases such as cancer, activation of Wnt/ $\beta$-catenin signaling is a target of interest in stem cell therapy and regenerative medicine. Recent high throughput screenings from chemical and biological libraries, combined with improved gene expression reporter assays of Wnt/ $\beta$-catenin activation together with rational drug design, led to the development of a myriad of Wnt activators, with different mechanisms of actions. Among them, Wnt mimics, antibodies targeting Wnt inhibitors, glycogen-synthase-3 $\beta$ inhibitors, and indirubins and other natural product derivatives are emerging modalities to treat bone, neurodegenerative, eye, and metabolic disorders, as well as prevent ageing. Nevertheless, the creation of Wnt-based therapies has been hampered by challenges in developing potent and selective Wnt activators without off-target effects, such as oncogenesis. On the other hand, to avoid these risks, their use to promote ex vivo expansion during tissue engineering is a promising application.
\end{abstract}

\section{Introduction}

Wnt signaling represents one of the multiple conserved pathways, including Notch, ${ }^{1}$ Hedgehog, ${ }^{2}$ transforming growth factor $\beta$ (TGF- $\beta$ )/bone morphogenetic protein (BMP) ${ }^{3}$ and Hippo, ${ }^{4}$ essential for embryonic development, the maintenance of stem cell (SC) proliferation, SC self-renewal, and tissue regeneration. ${ }^{5} \mathrm{Wnt}$ signaling initiates multiple functionally divergent pathways. Among them, the best characterized is the Wnt/ $\beta$-catenin pathway, often referred to as the canonical pathway. It regulates the expression of $\beta$-catenin-dependent gene expression that directs embryogenesis and SC fate. Wnt signaling can become aberrant, triggering different types of diseases, such as cancer. ${ }^{6}$ However, insufficiency in Wnt signaling compromises tissue renewal, as reported in osteoporosis and bone disorders, ${ }^{7}$ vitiligo, $^{8}$ or neurodegeneration. ${ }^{9}$ Reciprocally, when overactivated, it triggers various types of cancers, such as colon, stomach, liver, breast, and ovarian. ${ }^{10}$ Thus, the search for Wnt signaling modulators, both inhibitors and activators, as potential drug therapies, has become an ongoing

\footnotetext{
${ }^{a}$ Stein Eye Institute, University of California, Los Angeles, CA, USA. E-mail: zheng@jsei.ucla.edu; Fax: +1-3107947906; Tel: +1-3102062173

${ }^{b}$ INSERM, UMRS1138, Team 17, From Physiopathology of Ocular Diseases to Clinical Development, Paris University, Centre de Recherche des Cordeliers, and Cornea Departement, Cochin Hospital, AP-HP, F-75014, Paris, France

${ }^{c}$ Molecular Biology Institute, University of California, Los Angeles, CA, USA
}

topic of interest for cancer, regenerative medicine, SC therapy, bone growth, and wound healing. ${ }^{11,12}$ Theoretically, by activating the Wnt signaling pathway, one could promote SC proliferation to restore tissue or organ impaired functions, the ultimate goal of SC therapy and regenerative medicine. Although no therapies affecting the pathway have so far been approved by the Food and Drug Administration, and only a few have entered in clinical trials, small-molecule Wnt regulators have been widely used as chemical biology tools for studying Wnt signaling in various biological settings. ${ }^{13,14}$ Those studies have greatly enriched our mechanistic understanding of the Wnt signaling cascades happening in human Wnt-related diseases, which is a prerequisite to the development of Wnt signaling-targeted therapy for cancer therapies and regenerative medicine. There are many excellent reviews on Wnt signaling inhibitors. ${ }^{15-17}$ Here, we focus on Wnt signaling activators, which include both biological and small-molecule reagents.

\section{Activation of Wnt signaling through Wnt proteins and Wnt mimics}

\section{a. Wnt proteins}

The human Wnt family consists of 19 homologs, encoding highly conserved hydrophobic glycoproteins that share common features, such as a specific signal sequence for secretion, highly 
charged amino acid residues, numerous glycosylation sites, and 22 cysteine residues. ${ }^{18,19}$ The secretion, transport, and reception of Wnt proteins are highly regulated processes, contextdependent, based on the expression profile of Wnt ligands, Wnt inhibitors, and frizzled (FZD) receptors and co-receptors, and the level of activity of intracellular Wnt signaling regulators, leading to a complex evaluation..$^{20,21}$ Wnt ligands are secreted growth factors that can activate at least three different Wnt pathways: the canonical Wnt/ $\beta$-catenin pathway, the non-canonical Wnt/planar cell polarity (PCP) pathway, and the non-canonical Wnt $/ \mathrm{Ca}^{2+}$ pathway. $^{22}$ The FZD proteins (10 members in humans) are involved in all three Wnt pathways; they are seventransmembrane receptors and have large extracellular $\mathrm{N}$-terminal cysteine-rich domains (CRDs) that provide a platform for Wnt binding. In the canonical pathway, when interacting with target cells, Wnt proteins bind a heterodimeric receptor complex consisting of FZDs and a single pass transmembrane molecule of the low-density lipoprotein receptor related protein (LRP) family, LRP5/6 protein ( 2 members in humans). ${ }^{6,23-25}$ Non-canonical Wnt signals are less well understood. They are transduced through FZD family receptors that oligomerize with receptor tyrosine kinase-like orphan receptor (ROR) and receptor like tyrosine kinase (RYK) coreceptors, reported $\beta$-catenin-independents. In the non-canonical Wnt/PCP pathway, upon Wnt activation, ras homolog family member A (RhoA) and c-jun N-terminal kinase (JNK) are activated, inducing downstream signaling of cell polarity and cell migration. In the non-canonical $\mathrm{Wnt} / \mathrm{Ca}^{2+}$ pathway, Wnt activation leads to a calcium influx into the cell, activating nuclear factor activated $\mathrm{T}$ cells (NFAT) and nemo-like kinase (NLK), transcription factors involved in cell fate and cell migration. ${ }^{26}$

Wnt signaling can be activated by adding Wnt proteins to cells by viral transduction, in a purified form or as conditioned medium. ${ }^{26-28}$ Cell lines producing active Wnt3a, Wnt5a, and Wnt5b have been generated ${ }^{29,30}$ and recombinant Wnt3a, Wnt5a, and Wnt5b are commercially available. In addition, Maltzahn et al. generated a truncated Wnt7a variant, consisting of the C-terminal 137 amino acids lacking the conserved palmitoylation sites, and showed that it activated the Wnt/ $\beta$-catenin pathway through binding to its receptor FZD7 after plasmid injection in skeletal muscle. ${ }^{31}$

However, Wnt proteins are highly hydrophobic due to their post-translational palmitoylation, an essential step for their secretion, function, and interaction with FZD receptors. ${ }^{6,19}$ Thus, they are difficult to manufacture consistently. Additionally, only a few are currently commercially available. Conditioned medium containing Wnt proteins may also contain other secreted factors induced by Wnt exposure. Furthermore, Wnt proteins are cross-reactive for multiple FZD receptors when overexpressed or applied at high dose. ${ }^{32,33}$ Hence, when using Wnt proteins, it has not been possible to activate selective FZD receptors, to explore the specific functions of each in different contexts, or to evaluate their therapeutic potentials.

\section{b. Wnt mimics}

Because Wnt binds to FZD and LRP5/6 and activates canonical Wnt signaling, it was reasoned that inducing the dimerization of FZD and LRP5/6 should also be able to induce Wnt signaling. ${ }^{14,34-36}$ Janda et al. first described a hydrophilic Wnt surrogate by linking antagonistic FZD and LRP5/LRP6-binding modules into a single polypeptide chain, in a bispecific binding approach. $^{35}$ The FZD binding module was designed and engineered de novo to bind the CRD of FZD8 and linked to the C-terminal domain of DKK1 (sc-Fv-DKK1c), binding LRP5/6. They were linked by a Gly-Ser polypeptide linker, forcing receptor heterodimerization that phenocopied Wnt/ $\beta$-catenin signaling in vitro and in vivo, while blocking endogenous Wnt binding. ${ }^{35}$ Using this approach, Zhang et al. created a Wnt mimic compound by linking a Wnt inhibitor binding to the CRD of FZD (named MFH) to the N-terminal region of DKK that binds to the first $\beta$-propeller domain of LRP6 (named ND) through a $\mathrm{MFH}$ free carboxyl group and a pentaethylene glycol spacer. ${ }^{14}$ They showed that the consolidated compound MFH-ND enhanced Wnt/ $\beta$-catenin activation and improved the progenitor cell phenotype of cultured limbal epithelial cells in vitro. As the maintenance of SC characteristics during culture expansion is essential for the success of cultivated limbal epithelial transplants, ${ }^{37}$ the small molecule generated in this study may be helpful in the development of pharmaceutical therapeutics to enhance SC culture in vitro or promote corneal wound healing in vivo. Tao et al., using the phage-displayed synthetic library F, went further into the bispecific Wnt surrogate concept: they engineered modular tetravalent antibodies FZD/ LRP agonists, named FLAgs. FLAgs are composed of human antibody domains, highly stable, and amenable to large-scale production, have predictable pharmacokinetics, and exhibit low immunogenicity. They enabled selective and robust activation of chosen FZD receptors in vitro. ${ }^{36,38}$ In the same approach, Chen et al. assembled various combinations of FZD and LRP binders, each with different stoichiometry, and tested their ability to activate the Wnt/ $\beta$-catenin pathway. ${ }^{34}$ They found that tetravalent binding of 2 FZDs and 2 LRP binders produced a stronger $\mathrm{Wnt} / \beta$-catenin activation in vitro compared with the bispecific Wnt surrogate. They provided a flexible platform of next generation Wnt surrogates targeting individual FZD or a combination of FZDs of desired specificity and activity.

With their high specificity, Wnt mimics can activate Wnt signaling with greater precision compared with Wnt proteins. Whether tetravalent Wnt surrogates are more efficient in activating the pathway compared with bispecific surrogates still remains to be elucidated. Miao et al. engineered a bispecific Wnt surrogate binding sc-Fv-DKK1c to DRPB_FZD7/8 (designed repeat protein binder) and purified it to select the FZD7/8 subtype. ${ }^{39}$ These next generation surrogate (NGS) Wnt were very potent at increasing the growth of different types of organoids (colon, pancreas, ovary, breast, and hepatocyte), acting synergically with R-spondin. Using dual-color singlemolecule fluorescence imaging and binding the dynamics of FZD8 and LRP5/6, they observed a principal cluster of $1: 1$ heterodimer. They concluded that tetrameric ligands are not the minimal multimerization unit necessary to activate the Wnt/ $\beta$-catenin signaling pathway. They further showed that NGS Wnt are systemically active in vivo and exhibits tissue 
selectivity (liver and small intestine) in conjunction with its FZD subtype specificity.

UM206 is another synthetic peptide ligand for FZD1 and FZD2 receptors through 13 amino acids common with Wnt3a or Wnt5A. ${ }^{40}$ The peptide has been shown to initiate activation of canonical Wnt signaling as demonstrated by increased Wnt/ $\beta$-catenin reporter activity. ${ }^{41}$ Attachment of UM206 to magnetic nanoparticles (MNPs) enables the ligand-MNP complex to be manipulated using magnetic fields, allowing control of Frizzled stimulation. Rotherham et al. showed that remote activation of UM206 by MNPs with magnetic field stimulation was feasible to activate the $\mathrm{Wnt} / \beta$-catenin pathway, promoting bone formation in chicks, and dopaminergic marker expression in rats' neurons. ${ }^{41,42}$ This makes Wnt signaling an important therapeutic target for neurogenerative diseases such as Parkinson's disease. ${ }^{42,43}$

\section{c. Recombinant Norrin}

Norrin is another cysteine-rich secreted protein, encoded by NDP gene, that binds with high affinity and specificity to FZD4 and LRP5/6, activates Wnt/ $\beta$-catenin, ${ }^{44}$ and has angiogenic and neuroprotective properties. ${ }^{45,46}$ Mutations of NDP are associated with Norrie disease and familial exudative vitreoretinopathy. ${ }^{47}$ Recombinant Norrin has been used to study Wnt/ $\beta$-catenin pathway activation and downstream effects in several tissues expressing FZD4, ${ }^{48}$ notably the brain, the inner ear, and the retina. ${ }^{45,46}$ It is a promising target to treat Norrie disease, retinopathy of prematurity, and other ocular diseases that involve ischemia-induced neovascularization. ${ }^{48}$

\section{Activation of Wnt signaling through inhibition of Wnt inhibitors}

Wnt signaling is regulated at different levels by a wide range of effectors, functioning as agonists, such as Wnt ligands, R-spondin (RSPO), and Norrin, or antagonists, such as DKKs, SFRPs, WIF-1, Wise/SOST, Cerberus, insulin-like growth-factor binding protein 4 (IGFBP-4), Shisa, Wnt-activated inhibitory factor 1 (Waif1/5T4), adenomatosis polyposis coli down-regulated 1 (APCDD1), and Tiki1. ${ }^{15}$ They can act either intracellularly, to modulate components of the signal transduction machinery, or extracellularly, to modulate ligand-receptor interactions. Antagonists and agonists are of great importance, as they control the fine-tuning of Wnt signaling and inhibit or activate Wnt-regulated embryogenic development, as well as SC fate, that can lead to cancer, or bone or metabolic diseases. ${ }^{16}$ LRP5/6 is a major target for drug development to treat osteoporosis and other bone diseases. ${ }^{7}$ Indeed, mutations of LRP5/6, DKK1, and sclerostin (encoded by the SOST gene), core or regulatory components of the Wnt/ $\beta$-catenin pathway, can lead to severe phenotypic defects, such as sclerosteosis or hereditary osteoporosis. ${ }^{15,49}$

\section{a. Anti-DKK monoclonal antibodies}

DKKs represent a family of evolutionary conserved secreted glycoproteins (4 members in humans) and share two CRDs. DKK1 specifically inhibits the Wnt/ $\beta$-catenin pathway by binding to LRP5/ 6 with high affinity ${ }^{15}$ and is involved in the pathogenesis of osteoporosis, ${ }^{50,51}$ solid cancers, ${ }^{11}$ neurodegenerative processes, and induction of apoptosis after neuronal injury. ${ }^{52,53}$ Thus, it is a rational target of Wnt-pro-signaling therapy. Several studies have shown that DKK1 neutralizing monoclonal antibodies (anti-DKK1 mAbs) can accelerate bone formation and increase bone mineral density in various animal models. ${ }^{54-58}$ BHQ880, ${ }^{59}$ DKN-01, ${ }^{60}$ and PF-04840082 ${ }^{61}$ are anti-DKK1 mAbs developed recently, and $\mathrm{BHQ} 880$ and $\mathrm{DKN}-01$ are in clinical trials for patients with multiple myeloma and solid tumors, such as cholangiocarcinoma, esophageal cancer, and gastric cancer. ${ }^{11}$ Anti-DKK1 mAbs may also be applicable for the treatment of immune evasion in cancer patients with DKK1 upregulation. ${ }^{62}$

Anti-DKK2 has been reported to improve glucose tolerance in a murine model of non-insulin dependent diabetes and might be a potential therapeutic target for treating noninsulin dependent diabetes. ${ }^{63}$

\section{b. Anti-sclerostin monoclonal antibodies}

Sclerostin is another secreted protein antagonizing Wnt/ $\beta$-catenin signaling by binding to LRP5/6. Sclerostin is highly and selectively expressed in osteoblasts and osteocytes, inhibits osteoblastogenesis, promotes osteoclastogenesis, and is involved in the pathogenesis of osteoporosis and cancer-associated osteolysis. $^{50,51}$ Thus, inhibition of sclerostin is another interesting target of Wnt/ $\beta$-catenin activation. Anti-sclerostin mAbs (romosozumab, blosozumab, and BPS804) $)^{64-66}$ have been developed and are in clinical trials for female postmenopausal patients with decreased bone mass density.

Mechanistic aspects of DKK-1 and sclerostin interactions with LRP5/6 receptors defined by in vitro, crystallographic, and genetic studies ${ }^{67}$ suggest that these proteins probably have both distinct and redundant roles in bone formation and repair. Florio et al. developed a bispecific heterodimeric antibody against sclerostin and DKK1 (Hetero-DS). ${ }^{68}$ They showed that Hetero-DS has a synergetic effect in bone formation and repair compared with sclerostin or DDK1 antibody alone.

\section{c. Recombinant R-spondin proteins and surrogates}

R-Spondin secreted proteins (RSPO1-4 in mammals) are defined by two N-terminal furin domains, a thrombospondin domain and a basic region. ${ }^{69-71}$ RSPOs interact on the cell surface with members of the LGR5 family to enhance Wnt signaling in various contexts, but do not activate in the absence of Wnts themselves. ${ }^{72-74}$ ZNRF3 and RNF43 are transmembrane molecules that downregulate Wnt signaling. In the absence of RSPOs, their E3 ubiquitin ligase activity leads to the internalization and degradation of FZD and LRP5/6 receptors. ${ }^{75,76}$ Binding of RSPOs to ZNRF3 downregulates the activity of ZNRF3, potentiating Wnt signaling through the antagonization of FZD and degradation of LRP5/6 receptors. ${ }^{75}$ The effect of RSPOs is very potent, and the coaddition of Wnts and RSPOs can result in Wnt/ $\beta$-catenin signaling activation that is hundred folds higher compared with the addition of Wnt alone. ${ }^{35}$ Recently, Lebensohn and Rohatgi have shown that RSPO2 and RSPO3 can potentiate Wnt signaling without LGRs, when the RSPO 
binds to heparan sulfate proteoglycans (HSPGs) on the cell surface via their thrombospondin and basic region domains. ${ }^{77}$ As Wnt signaling enhancers, recombinant RSPOs have been explored in the field of regenerative medicine, especially in the small intestine, where they can promote the renewal of SC in vitro and at the base of the crypt in vivo. ${ }^{78,79}$ Adding a level of complexity, Yan et al. reported that Wnt ligands and RSPOs play non-equivalent roles in intestinal SC self-renewal through a feedback loop, in which Wnt ligands drive the expression of LGR5, and RSPOs induce SC expansion. ${ }^{80}$ This suggests that targeting the pathways either separately or simultaneously might present different clinical outcomes. Nevertheless, RSPOs are promising candidates to selectively boost innate Wnt activity while avoiding off-target effects associated with global Wnt agonism. To improve the specificity of RSPO targets, Luca et al. engineered synthetic protein ligands, LGR- and HSPGindependent, from a published yeast display library of approximately $1 \times 10^{9}$ sequences derived from human B-cells. ${ }^{81}$ These RSPO surrogates function by coupling the RNF43 or ZNRF3 extracellular domain to an immune cell surface marker (CD25), known to undergo internalization upon ligand binding, thereby mimicking RSPO-mediated sequestration of RNF43/ZNRF3. ${ }^{82}$ RSPO surrogates phenocopy RSPO-mediated Wnt signal enhancement, selectively boosting Wnt signaling in CD25+ reporter cells and human colon organoids. Their modular design could be adapted to targets of any cell type, a feature that has major implications for the development of Wnt-based therapeutics. ${ }^{82}$

Zhang et al. also engineered tissue-specific RSPO-like Wnt signaling enhancers to liver-specific receptors, rather than LGRs. ${ }^{83}$ They mutated RSPO in the furin 2 domain to specifically antagonize the LGR interaction, rendering the molecule solely dependent on E3 ligases for activity. They then fused the mutated RSPO to single-chain variable fragments or full-length IgG of a liver-specific receptor, ASGR1. They showed that the coupling of the bispecific RSPO surrogate enhanced Wnt/ $\beta$-catenin in vitro, and that its activity was limited to ASGR1 positive cells. Additionally, systemic administration of the RSPO mimic in mice preferentially upregulated canonical Wnt target genes, promoting SC proliferation in the liver, but not in the small intestine. ${ }^{83}$

\section{d. Anti-SFRP-1 monoclonal antibodies}

SFRP is a family of secreted Wnt inhibitors (5 members in humans) that can sequester Wnt ligands or bind to the CRD of FZD to compete with Wnt binding, inhibiting both canonical and non-canonical Wnt pathways. ${ }^{84}$ Loss of SFRP-1 reduced bone accrual through a combination of decreased cellular proliferation, differentiation, and activity, as well as led to increased apoptosis. ${ }^{85}$

Bodine et al. developed small molecules that bind to and inhibit SFRP-1. ${ }^{86}$ They screened a library of over 440000 druglike compounds for SFRP-1 human inhibitors. Using luciferase assays, they discovered that the N-Substituted Piperidinyl Diphenylsulfonyl Sulfonamide (WAY-316606) selectively binds to SFRP-1, thereby activating the Wnt/ $\beta$-catenin pathway. ${ }^{86-88} \mathrm{It}$ also promoted bone formation and remodeling in vivo.

\section{e. Anti-NOTUM small molecules}

Wnt ligands are post-transcriptionally modified by palmitoleoylation of a conserved serine by Porcupine, an event that is required for Wnt trafficking and binding to Frizzled receptors. NOTUM is a serine hydrolase, involved in the deacylation of the palmitoylated serine residue, leading to $\mathrm{Wnt} / \beta$-catenin inactivation. ${ }^{89}$ Only a few reports describe the use of NOTUM inhibitors, such as LP-922056, to activate Wnt signaling, promote bone formation, and treat osteoporosis in animal models. ${ }^{90,91}$ However, these compounds could present off-target effects, as they can penetrate the blood-brain barrier. Suciu et al., using an activity-based protein profiling method, engineered a more specific inhibitor, $N$-hydroxyhydantoin carbamate inhibitor (ABC99), that potently and selectively inhibits NOTUM, while the activation of the Wnt/ $\beta$-catenin pathway was confirmed in vitro using a super TOPFlash assay. ${ }^{92}$ However, it tends to form a covalent adduct with NOTUM, limiting its use in vivo. Atkinson et al. recently developed 2-phenoxyacetamide compounds as specific NOTUM inhibitors that restore $\mathrm{Wnt} / \beta$-catenin signaling in vitro. ${ }^{93}$ They are interesting compounds to study in vitro models of Alzheimer's disease, but to date, these compounds are not metabolically stable.

Taken together, these data suggest that Wnt signaling modulators' antibodies could be used as therapeutic agents to stimulate bone formation after injury or disease, while presenting attractive manufacturing attributes.

\section{Activation of Wnt signaling through disruption of $\boldsymbol{\beta}$-catenin degradation}

In the absence of canonical Wnt signaling, $\beta$-catenin, binding with adenomatous polyposis coli (APC) and Axin, is phosphorylated by casein kinase $1 \alpha(\mathrm{CK} 1 \alpha)$ and glycogen synthase kinase $3 \beta$ (GSK-3 $\beta$ ), forming a destruction complex. Phosphorylated $\beta$-catenin is then ubiquitinated by $\beta$ TRCP1 or $\beta$ TRCP2 for cytosolic proteasome degradation. In the presence of canonical Wnt, FZD receptors and LRP5/6 coreceptors oligomerize, and Disheveled (DVL) is phosphorylated by CK $1 \alpha$ and GSK- $3 \beta$, recruiting Axin to the phosphorylated tail of LRP5/6. The destruction complex falls apart, and $\beta$-catenin is released from phosphorylation by CK1 $\alpha$ and GSK- $3 \beta$, is stabilized in the cytosol, and can then accumulate in the nucleus. Active nuclear $\beta$-catenin is complexed with T-cell factor/lymphoid enhancer factor (TCF/LEF) family transcription factors, targeting the transcription of downstream target genes mostly involved in cell proliferation, such as AXIN2, C-MYC, and CCND1. ${ }^{6}$

\section{a. GSK-3 $\beta$ inhibitors}

Currently, GSK-3 $\beta$ inhibitors are the most widely used Wnt/ $\beta$-catenin activators. By binding GSK-3 $\beta$, the activity of the enzyme is inhibited, and the destruction complex falls apart, allowing $\beta$-catenin, which does not have intrinsic enzymatic activity, to accumulate in the nucleus to activate transcription factors of targeted genes. ${ }^{94}$ 
i. Lithium chloride. Lithium chloride ( $\mathrm{LiCl}$ ) is a chemical compound that has been used for decades as a mood stabilizer for bipolar disorder, schizophrenia, depression, and other mental illnesses, with little toxicity. ${ }^{95}$ Among several targets, LiCl has been shown to directly inhibit GSK-3 $\alpha$ and GSK-3 $\beta .^{94}$ Its use decreases the expression of cyclin A2 and increases the expression of cyclin D1, both of which are genes regulating the cell cycle. ${ }^{96} \mathrm{LiCl}$ promotes neural SCs toward neuronal differentiation in vitro, improving the symptoms of Parkinson's disease in animal models. ${ }^{97} \mathrm{LiCl}$ also improves osteoblast proliferation in vitro ${ }^{96}$ and osteogenesis in vivo at concentrations below the IC50 of $2 \mathrm{mM}$ for GSK-3 $\beta$ inhibition in vivo. ${ }^{96,98} \mathrm{LiCl}$ has also been reported as a therapeutic target of non-insulindependent diabetes mellitus. ${ }^{99-101}$

ii. Indirubins and derivatives. Indirubins, discovered from edible mollusks and plants, are potent and reversible GSK-3 $\beta$ inhibitors and are the first pharmacological agents shown to maintain self-renewal in human and mouse embryonic SCs. ${ }^{102,103}$ From a high-throughput screening of thousands of different natural products, an improved and more specific GSK-3 $\beta$ inhibitor, 6-bromo-indirubin-30-oxime (6-BIO), was synthetically derived, ${ }^{104}$ demonstrating anti-cancer, ${ }^{105,106}$ neuroprotective functions during senescence, ${ }^{104}$ and proliferative activity in cardiomyocytes. ${ }^{107}$ The development of the medicinal chemistry of indirubins is ongoing to provide more products with improved characteristics. For example, Moon et al. screened for indirubin cyclin dependent kinase inhibitors to develop cancer, psoriasis, and chemotherapy-associated side effect preventive drugs. ${ }^{108}$ They identified a series of Wnt activators from these indirubin derivative CDK inhibitors. ${ }^{109}$ Among them, indirubin-5-nitro-30-oxime (INO) was reported as a potent Wnt/ $\beta$-catenin activator using a TOPFlash assay. ${ }^{109}$ Indirubins and their derivatives are powerful and robust $\mathrm{Wnt} / \beta$-catenin activators and remain the gold standards in experiments related to Wnt signaling activation alongside lithium chloride. ${ }^{110}$

iii. Other natural products. Gilbert et al. reported that (hetero)arylpyrimidines were GSK-3 $\beta$ inhibitors with osteogenic activity in an animal model. ${ }^{111}$ Other natural products from plants have also been identified to inhibit GSK-3 $\beta$, such as andrographolide, from Andrographis paniculata, ${ }^{112}$ Euonymus fortunei, Amygdalus communis, Flavone fukugetin, and Garcinia xanthochymus. ${ }^{113}$

iv. Small molecules. Ding et al. performed a highthroughput phenotypic cell-based screen of kinase-directed combinatorial libraries, and found that a 4,6-disubstituted pyridopyrimidine, TWS119, could induce neurogenesis in murine embryonic SCs. ${ }^{114}$ Through affinity-based and biochemical methods, they showed that the TWS119 target was GSK-3 $\beta$. Using a high-throughput cell-based assay (Asahi Kasei's proprietary chemical library searching), Miyabayashi et al. developed IQ-1, a small molecule targeting PP2A, a phosphatase of the destruction complex that inhibits GSK-3 $\beta$. IQ-1 activated Wnt/ $\beta$-catenin and prevented spontaneous differentiation of mouse embryonic SCs. ${ }^{115}$ These two examples provide insight into the molecular mechanisms that control SC fate, and may ultimately be useful for in vivo SC biology and therapy.
Arylindolemaleimide (SB-216763) and anilinomaleimide (SB-415286) are maleimide derivatives identified from a highthroughput screen of the SmithKline Beecham compound bank against rabbit GSK-3. ${ }^{116}$ They inhibit GSK-3 $\alpha$ and GSK-3 $\beta$ and show the potential induction of transcription of a Wnt/ $\beta$-catenin-mediated gene expression in a dose-dependent manner. ${ }^{117}$ These compounds were also elucidated as potential therapeutic effectors for diseases associated with high GSK-3 $\beta$ activity, such as non-insulin dependent diabetes mellitus ${ }^{99-101}$ and neurogenerative disease. ${ }^{118,119}$

CHIR99021 is an amino pyrimidine derivative that was first shown to promote the self-renewal of mouse embryonic SCs. ${ }^{120}$ It has been used in various in vitro models of Wnt signaling activation to explore its mechanistic and potential therapeutic benefits. ${ }^{120}$ CHIR99021 has been shown to promote remodeling of lung and cardiac tissues after injury. ${ }^{121,122}$ In vitro, CHIR99021 can promote the de novo formation of hair follicles, ${ }^{123}$ and maintain the self-renewal of mouse intestine LRG5+ intestine SCs. ${ }^{124}$ As for the other GSK-3 $\beta$ inhibitors, cross-talk between Wnt/ $\beta$-catenin and other pathways are reported, and can promote differentiation in other cell lines. ${ }^{125,126}$ Future studies using CHIR99021 are necessary to decipher the different pathways activated beyond Wnt.

L807mts is a new highly specific GSK-3 $\beta$ inhibitor, acting through a substrate-to-inhibitor conversion mechanism that occurs within the catalytic site of the enzyme. ${ }^{127}$ L807mts showed a safe profile in an animal model of Alzheimer's disease, improving autophagic flux, the clearance of $\beta$ amyloid deposits, and cognitive skills, while reducing inflammation.

Pharmacological enhancement of Wnt/ $\beta$-catenin signaling is linked to antiproliferative/metastatic activity in melanoma cells. ${ }^{128}$ This has been reported after the use of Riluzole and BAY 36-7620. ${ }^{128}$ These GSK-3 $\beta$ inhibitors decrease the proliferation and increase the differentiation of melanoma-induced cells in vitro when combined with Wnt3a. ${ }^{128}$ Atkinson et al. engineered a highly selective small molecule inhibitor of GSK-3 $\beta$, LY2090314, capable of activating the Wnt/ $\beta$-catenin pathway and inducing apoptosis in human melanoma tumor cells at nanomolar concentrations (IC50 approx. 10nM). ${ }^{129}$ In vivo, LY2090314 elevated Axin2 gene expression. They provided a proof-of-concept study supporting the use of small molecule Wnt activators in the treatment of melanoma, which is now extended to a phase 1 clinical trial for melanoma therapy. Moreover, Wnt activators have the ability to increase the proliferation of normal tissues, and further investigation of GSK-3 $\beta$ inhibitors for melanoma therapy is necessary in regard to their effects on healthy tissues. Future directions include the development of small GSK-3 $\beta$ inhibitors designed to target substrate binding sites of interest. ${ }^{130}$ However, GSK-3 $\beta$ inhibitors can also block the action of other kinases, such as GSK- $3 \alpha{ }^{102}$ In addition, GSK-3 $\beta$ is implicated in many other critical signaling pathways ${ }^{131,132}$ that could be dysregulated by drugs targeting this enzyme for Wnt activation, highlighting the risk of off-target effects. ${ }^{133,134}$ 


\section{b. Casein kinase $1 \alpha$ inhibitors}

Casein kinase $1 \alpha(\mathrm{CK} 1 \alpha)$ is a member of the CK1 family of proteins that has broad serine/threonine protein kinase activity. ${ }^{135}$ Along with GSK-3 $\beta$, APC, and Axin, CK1 $\alpha$ is a component of the $\beta$-catenin destruction complex promoting its ubiquitination and proteosomal degradation in the absence of Wnt ligands. ${ }^{135} \mathrm{CK} 1 \alpha$ is a negative regulator of Wnt signaling. $\beta$-Catenin is phosphorylated by $\mathrm{CK} 1 \alpha$ at Ser 45 , which leads to GSK-3 $\beta$-dependent phosphorylation at Ser33/37 and Thr41, and subsequent degradation. ${ }^{136}$ APC, essential for $\beta$-catenin binding, is also phosphorylated at Ser1504/1505/1507/1510 by $\mathrm{CK} 1 \alpha^{137}$

Compounds targeting CK1 have also been developed, such as ricinine ${ }^{138}$ which shows the ability to activate Wnt/ $\beta$-catenin signaling in vitro. ${ }^{139}$ However, CK1 $\alpha$ is also involved in many other signaling pathways, such as nuclear factor kappa-lightchain-enhancer of activated $B$ cells (NF- $\mathrm{B}$ ), Hedgehog, autophagy, and phagocytosis among others. ${ }^{135}$ So far, no inhibitors that selectively target CK1 $\alpha$ have been developed. Therefore, the available compounds are mostly used to study CK1 $\alpha$ function.

\section{Activation of Wnt signaling of unknown mechanisms with compounds identified by high-throughput screening}

There have been many high-throughput screening efforts of chemical and/or biological compounds searching for Wnt inhibitors because of their role in the development of anticancer therapies. These screenings led to the development of an increasing number of small molecule Wnt inhibitors. As "side products" of these studies, Wnt activators are often identified as attractive targets for SC therapy. Cell-based assays, using cells very sensitive to Wnt activation, such as HEK 293 cells exposed to Wnt3a, ${ }^{140}$ are usually used to detect and quantify Wnt/ $\beta$-catenin gene activation, using luciferase reporter assays. ${ }^{141,142}$ With this approach, many small molecules activating Wnt pathways have been discovered, but for most of them, the underlying mechanisms of action require further investigation. For example, Liu et al. described 2-amino-4-[3,4(methylenedioxy)benzylamino]-6-(3-methoxyphenyl)pyrimidine (AMBMP) as a GSK-3 $\beta$ independent $\mathrm{Wnt} / \beta$-catenin activator. ${ }^{143}$ AMBMP was reported to attenuate liver injury and improve survival after hepatic ischemia/reperfusion. ${ }^{144}$ Zhang et al. identified QS-11 as a Wnt/ $\beta$-catenin activator that activates a small-GTPase, ARFGAP1. ${ }^{145}$ Gwak et al. identified SKL001 as an agonist of the Wnt/ $\beta$-catenin pathway, disrupting the Axin/ $\beta$-catenin interaction and inhibiting the destruction complex. ${ }^{146}$

Using natural products with various known bioactivities to design multifarious oxepane scaffolds, Basu et al. identified other Wnt activators, Wntepanes, that act synergistically with the Wnt3a protein by binding to van-Gogh-like 1 (Vangl1), ${ }^{140}$ a transmembrane co-receptor of the non-canonical pathway ${ }^{147}$ that mediates cross-talk between canonical and non-canonical pathways. ${ }^{148}$ Wntepanes could be used as tools for further studying Vangl1 functions and relations with the canonical pathway. High-throughput pipelines are also widely used to target Wnt inhibitors, such as anti-FZD and anti-LRP5/6, or downstream nuclear proteins of the pathway, with the goal of developing new cancer therapies. ${ }^{149,150}$ By binding two inhibitors, it possible to engineer Wnt mimics, as did Chen et al., ${ }^{34}$ Janda et al., ${ }^{35}$ Tao et al., ${ }^{36}$ and Zhang et al., ${ }^{14}$ when coupling anti-FZD with anti-DKK1 small molecules.

Extensive screenings of the natural product library also identified many plant extracts that can activate Wnt/ $\beta$-catenin. ${ }^{12}$ However, again, the underlying mechanisms of action remain largely unknown. Among them, Sanguisorba officinalis L. and flavonoids are potential drug therapeutic agents against non-alcoholic fatty liver disease ${ }^{151}$ obesity, ${ }^{152}$ and osteoporosis. ${ }^{153}$ Hovenia dulcis, ${ }^{154}$ l-quebrachitol (2-O-methyl1-chiro-inositol), ${ }^{155}$ Rehmannia sp., ${ }^{156}$ Salvia miltiorrhiza, ${ }^{157}$ Euodia sutchuenensis Dode, ${ }^{158}$ the Siegesbeckia genus, ${ }^{159}$ Guava triterpeneenriched extracts, ${ }^{160}$ Morinda citrifolia, ${ }^{161}$ rosmarinic acid, ${ }^{162}$ Curculigo orchioides, ${ }^{163}$ Bauhinia championii, ${ }^{164}$ liposaccharides from Escherichia coli, ${ }^{165}$ and the well-known Ginkgo biloba ${ }^{166-168}$ are among the Wnt/ $\beta$-catenin activators promoting osteoblastogenesis and bone density in cell models in vitro and animal models. Nevertheless, it is possible that activation of Wnt signaling arises from cross-talk between Wnt and other osteogenic pathways, rather than a direct activation of the Wnt pathway by a given compound.

Moreover, extracts from Aconitum ciliare are described as hair growth-promoting, ${ }^{169}$ while the extract from Vernonia anthelmintica $^{8}$ is a potential drug to treat vitiligo through its ability to promote melanin synthesis. In the nervous system, cannabidiol, from Cannabis sativa, ${ }^{170}$ is a GSK-3 $\beta$ inhibitor that has a neuroprotective effect in a cellular model of Alzheimer's disease. Simvastatin ${ }^{171}$ from Aspergillus terreus and curcumin $^{172}$ can also promote neurogenesis and reverse cognitive deficits in Alzheimer's disease models.

Extracts from marine natural products (deep-sea invertebrates and algal metabolites) revealed Molpadia musculus, ${ }^{173}$ Phelliactis callicyclus, ${ }^{173}$ Crassostrea gigas, ${ }^{174}$ Undariopsis peterseniana, ${ }^{174}$ Capsosiphon fulvescens, ${ }^{175}$ and Chlorella vulgaris ${ }^{176}$ as Wnt/ $\beta$-catenin activators. ${ }^{173}$ Even if indirubins and their derivatives such as 6-BIO remain the gold standard to explore $\mathrm{Wnt} / \beta$-catenin activation, other natural marine products could become drug candidates, calling for more attention.

\section{Potential application of Wnt activators}

Wnt activators can have several applications for regenerative medicine and SC therapy. They can be used as tools to deeply understand SC biology, a prerequisite to the development of Wnt-related therapies. ${ }^{177-179}$ Despite the multitude of potential points of interventions in the pathway, as well as the numerous reagents that can interfere with these targets, it is still unclear 
Table 1 Wnt activators, mechanism of actions, potential therapeutic effects, and stage of development

\begin{tabular}{|c|c|c|c|c|}
\hline Name & Target & Therapeutic potential & $\begin{array}{l}\text { Stage of } \\
\text { development }\end{array}$ & Ref. \\
\hline \multicolumn{5}{|l|}{ Wnt mimics } \\
\hline \multicolumn{5}{|l|}{ Small molecules } \\
\hline Wnt surrogates & $\begin{array}{l}\text { Anti-FZD and anti-LRP5/ } \\
6, \text { bispecific }\end{array}$ & $\begin{array}{l}\text { Bone formation, stem cell ex vivo } \\
\text { expansion, metabolic disorders }\end{array}$ & Reagent & Janda et $a l .{ }^{35}$ \\
\hline MFH-ND & $\begin{array}{l}\text { Anti-FZD and anti-LRP5/ } \\
6 \text {, bispecific }\end{array}$ & Limbal stem cell ex vivo expansion & Reagent & Zhang et al. ${ }^{14}$ \\
\hline FLAgs & $\begin{array}{l}\text { Anti-FZD and anti-LRP5/ } \\
6, \text { tetravalent }\end{array}$ & $\begin{array}{l}\text { Intestinal organoid ex vivo } \\
\text { expansion }\end{array}$ & Reagent & Tao et al. ${ }^{36}$ \\
\hline Wnt surrogates & $\begin{array}{l}\text { Anti-FZD and anti-LRP5/ } \\
6 \text {, tetravalent }\end{array}$ & $\begin{array}{l}\text { Intestinal organoid ex vivo } \\
\text { expansion }\end{array}$ & Reagent & Chen et $a l^{34}$ \\
\hline Next generation surrogates & FZD & $\begin{array}{l}\text { Intestinal, breast, ovary organoid } \\
\text { ex vivo expansion }\end{array}$ & Reagent & Miao et al. ${ }^{39}$ \\
\hline UM206 & FZD1 and FZD2 & $\begin{array}{l}\text { Remote activation of FZD using } \\
\text { magnetic nanoparticles } \\
\text { Bone formation, Parkinson's } \\
\text { disease }\end{array}$ & Reagent & Rotherham et al. ${ }^{41}$ \\
\hline \multicolumn{5}{|c|}{ Recombinant R-spondin proteins and surrogates } \\
\hline Recombinant RSPO & RSPO & $\begin{array}{l}\text { Small intestine stem cell ex vivo } \\
\text { expansion }\end{array}$ & Reagent & Lebensohn and Rohatgi ${ }^{77}$ \\
\hline RSPO surrogates & RNZ43/ZNF43 and CD25 & $\begin{array}{l}\text { Intestinal organoid ex vivo } \\
\text { expansion }\end{array}$ & Reagent & Yan et al. ${ }^{80}$ \\
\hline RSPO surrogates & $\begin{array}{l}\text { Mutated RSPO and } \\
\text { ASGR1 }\end{array}$ & Hepatocyte stem cell expansion & Reagent & Zhang et al. ${ }^{83}$ \\
\hline \multicolumn{5}{|l|}{ Inhibition of Wnt inhibitors } \\
\hline BHQ880 & Anti-DKK1 mAb & Osteoporosis, cancer drug therapy & Phase 1 & Fulciniti et $a .^{59}$ \\
\hline DKN-01 & Anti-DKK1 mAb & Osteoporosis, cancer drug therapy & Phase 1 & Bendell et al. ${ }^{60}$ \\
\hline PF-04840082 & Anti-DKK1 mAb & Osteoporosis & Reagent & Betts et $a l^{61}$ \\
\hline Anti-DKK2 & $\begin{array}{l}\text { Animal model knockout } \\
\text { for DKK2 }\end{array}$ & Glucose intolerance & In vivo model & Li et $a .^{55}$ \\
\hline Blosozumab & Anti-sclerostin mAb & Osteoporosis & Phase 2 & Recker et $a l^{66}$ \\
\hline BPS804 & Anti-sclerostin mAb & Osteognenis imperfecta & Reagent & Roschger et al. ${ }^{65}$ \\
\hline Romosozumab & Anti-sclerostin mAb & Osteoporosis & Phase 3 & McClung et $a l^{64}$ \\
\hline WAY-316606 & Anti-SFRP1 & Osteoporosis & Reagent & Bodine et $a l^{86}$ \\
\hline LP-922056 & NOTUM inhibitor & In vitro assays & Reagent & Traver et al. Brommage et al..$^{90}$ \\
\hline ABC-99 & NOTUM inhibitor & In vitro assays & Reagent & Suciu et $a l^{92}$ \\
\hline 2-Phenoxyacetamides & NOTUM inhibitor & In vitro assays & Reagent & Atkinson et al. ${ }^{93}$ \\
\hline \multicolumn{5}{|l|}{ GSK-3 $\beta$ inhibitors } \\
\hline Lithium chloride & GSK-3 inhibitor & $\begin{array}{l}\text { Mood disorder, neurodegenera- } \\
\text { tive disease, osteoporosis, non- } \\
\text { insulin dependent diabetes } \\
\text { mellitus }\end{array}$ & $\begin{array}{l}\text { Phase } 4 \text { (mood } \\
\text { disorder) Reagents } \\
\text { (osteoporosis, diabetes } \\
\text { mellitus) }\end{array}$ & $\begin{array}{l}\text { Hedgepeth et al., }{ }^{94} \text { Freland } \\
\text { et al. }{ }^{55} \text { Rattanawarawipa } \\
\text { et al. }{ }^{96} \text { Qi } \text { et al. },{ }^{97} \text { Galli } \text { et al. }{ }^{98}\end{array}$ \\
\hline Indirubins & GSK-3 $\beta$ inhibitor & $\begin{array}{l}\text { Mouse embryonic stem cell ex vivo } \\
\text { expansion }\end{array}$ & Reagent & Sato et al. ${ }^{103}$ \\
\hline $\begin{array}{l}\text { 6-Bromo-indirubin-30- } \\
\text { oxime (6-BIO) }\end{array}$ & GSK-3 $\beta$ inhibitor & $\begin{array}{l}\text { Neurodegenerative disease, can- } \\
\text { cer drug therapy, cardio- } \\
\text { protection }\end{array}$ & Reagent & $\begin{array}{l}\text { Sklirou et al. }{ }^{104} \text { Blazevic } \\
\text { et al., }{ }^{105} \text { Eisenbrand } \text { et al. }{ }^{106} \\
\text { Tseng } \text { et al. }{ }^{107}\end{array}$ \\
\hline $\begin{array}{l}\text { Indirubin-5-nitro-30-oxime } \\
\text { (INO) }\end{array}$ & GSK-3 $\beta$ inhibitor & Cancer drug therapy & Reagent & Moon et al. ${ }^{108}$ \\
\hline (Hetero)arylpyrimidines & GSK-3 $\beta$ inhibitor & Osteoporosis & Reagent & Gilbert et al. ${ }^{111}$ \\
\hline \multicolumn{5}{|l|}{ Small molecules } \\
\hline TWS119 & GSK- $3 \beta$ inhibitor & Neurodegenerative disease & Reagent & Ding et al. ${ }^{114}$ \\
\hline IQ-1 & GSK-3 $\beta$ inhibitor (PP2A) & $\begin{array}{l}\text { Mouse embryonic stem cell ex vivo } \\
\text { expansion }\end{array}$ & Reagent & Miyabayashi et al. ${ }^{115}$ \\
\hline SB-216763 & GSK-3 $\beta$ inhibitor & $\begin{array}{l}\text { Neurodegenerative disease, dia- } \\
\text { betes mellitus }\end{array}$ & Reagent & $\begin{array}{l}\text { Eldar-Finkelman et al. }{ }^{99} \text { Taka- } \\
\text { shima } \text { et al. }{ }^{118}\end{array}$ \\
\hline SB-415286 & GSK-3 $\beta$ inhibitor & $\begin{array}{l}\text { Neurodegenerative disease, dia- } \\
\text { betes mellitus }\end{array}$ & Reagent & $\begin{array}{l}\text { Eldar-Finkelman et al., }{ }^{99} \text { Taka- } \\
\text { shima } \text { et al. } .^{118}\end{array}$ \\
\hline CHIR99021 & GSK-3 $\beta$ inhibitor & $\begin{array}{l}\text { Cardiac, lung, hair follicle, small } \\
\text { intestine stem cell expansion }\end{array}$ & Reagent & $\begin{array}{l}\text { Martin et al., }{ }^{122} \text { Zhang et al., }{ }^{121} \\
\text { Yoshida et al. }{ }^{123} \text { Yin et al. }{ }^{224}\end{array}$ \\
\hline L807mts & GSK-3 $\beta$ inhibitor & Neurodegenerative disease & Reagent & Licht-Murava et al. ${ }^{127}$ \\
\hline LY2090314 & GSK- $3 \beta$ inhibitor & Melanoma & Phase 1 & Atkinson et al. ${ }^{129}$ \\
\hline $\begin{array}{l}\text { CK-1 inhibitors } \\
\text { Ricinine }\end{array}$ & CK-1 inhibitor & In vitro assays & Reagent & Ohishi et al. ${ }^{138}$ \\
\hline
\end{tabular}


Table 1 (continued)

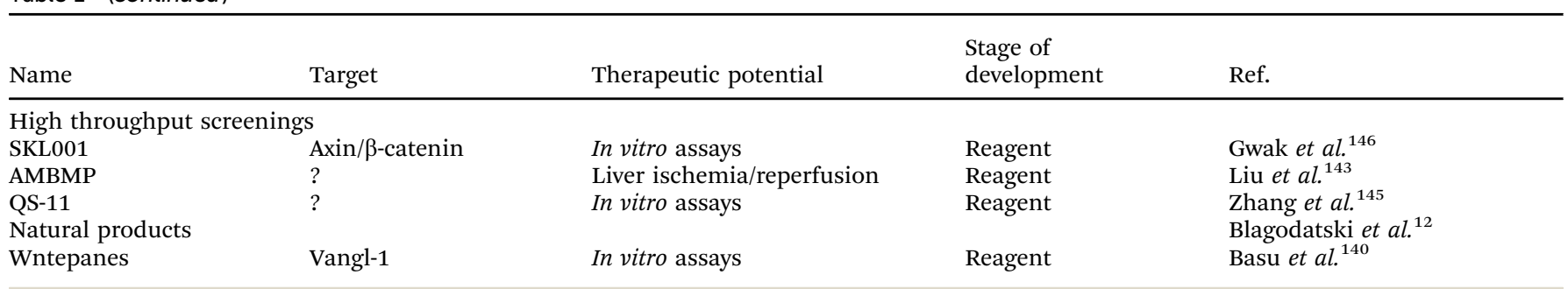

which approach will be the most efficient and safe. Wnt proteins are receptor-specific, useful for developing models that explore the signaling steps. Nevertheless, only a few Wnt ligands are available, and they are difficult to manufacture. In contrast, Wnt antibodies and Wnt mimics can be easily produced and start to offer insight into a better understanding of the complex pathway. Numerous compounds developed by high-throughput screening also seem to be potent to activate the Wnt/ $\beta$-catenin pathway, even if the underlying mechanisms of action remain unclear. Yet, the functions of single Wnt activators are not equal. Wnt mimics or proteins themselves are not limited to canonical or non-canonical activation but depend on the multiple pathways activated by distinct sets of receptors. For example, FZD receptors can activate both canonical and noncanonical pathways; thus, Wnt activators targeting FZD can have broad spectrum effects on both pathways. ${ }^{180,181}$ On the other hand, Wnt activators targeting molecules restricted to the canonical pathway, such as GSK-3 $\beta$ inhibitors or RSPOs, are canonical Wnt activators only. When developing Wnt activators for therapeutic purposes, these considerations are critical with regard to the expected effect on specific SCs. Therefore, the ability to activate different Wnt signaling pathways makes these reagents perfect tools for dissecting the regulating roles of different Wnt pathways in SCs.

Nevertheless, activating Wnt in vivo is a promising strategy to promote SC renewal and tissue homeostasis and repair, and prevent ageing. ${ }^{16}$ SC niches are three-dimensional, highly organized microenvironments that shelter SCs. ${ }^{182}$ SCs rely on interactions with their immediate niche to proliferate, migrate, and differentiate, ${ }^{183,184}$ as the result of complex molecular cross-talk with neighboring niche cells, and soluble factors such as Wnt molecules. ${ }^{185,186}$ The ability of Wnt activators to promote SC proliferation, the purpose of SC therapy, poses safety concerns, as dysregulation in the mechanisms that keep SCs in a quiescent, non-proliferating state can lead to cancer. ${ }^{187}$ Overactivation of Wnt signaling has been reported in numerous cancer types. ${ }^{188} \mathrm{Wnt}$ is a powerful and complex morphogen, temporal, dosage, and tissue specific, that exhibits numerous cross-talks with other crucial signaling pathways. Targeting such major developmental pathways utilized by both physiological SCs and by cancer SCs may have dramatic teratogenic effects and poses safety concerns given the duality of such therapeutics. ${ }^{139}$ Off-target and cancerogenic risks of these new therapies, if used systemically for a prolonged time, are dreaded complications. ${ }^{139}$ Activating Wnt for specific tissue repair in vivo will require a fine balance, where the targeted SC proliferation will not interfere with other tissue homeostasis. It is a current limitation of the use of Wnt activators. GSK-3 $\beta$ inhibitors can trigger cross-talks with other pathways. Therefore, broad spectrum Wnt mimics, due to their low specificity, raise the question of off-target effects. Besides LiCl, clinically used for decades to treat mood disorders with very low side effects, ${ }^{94}$ only a few, mostly targeting bone disorders, reached Phases 1 and 2 of clinical trials. For example, romosozumab ${ }^{64}$ and blosozumab, ${ }^{66}$ by targeting bone-specific sclerostin, are expected to lower the risks of long-term off-target effects.

Another application of Wnt activators, which is relatively safer, is to promote SC expansion in vitro. Models of SC cultures are fundamental to understand the mechanism of SC regulation, as well as to promote their expansion in vitro for regenerative medicine purposes via SC transplantation. These models must provide structural support and a variety of growth factors acting as a SC niche to allow their proliferation and preservation. In vitro cultivation of human epithelial cells was developed by Howard Green in the 1960 s. ${ }^{189}$ Initially, SC expansion consisted of a co-culture of human epidermal keratinocytes with 3T3 mouse embryonic fibroblasts, functioning as feeder cells. It led to the first SC therapy using cultured cells. ${ }^{190-192}$ It was later applied to other SCs, such as limbal SCs. ${ }^{193,194}$ However, these common methods are exposed to a xenobiotic risk of contamination for SC transplantation. To overcome this risk, different biological and synthetic materials that mimic the niche can be used as carriers for SC culture, such as amniotic membranes, fibrin, collagen, and silicon hydrogels. ${ }^{195,196}$ Developing xenobiotic-free culture systems would require additional factors that are capable of activating the Wnt pathways required for SC proliferation, and a scaffold on which to grow the SCs. Collagen/hydrogel scaffolds reported recently demonstrated the possibility of generating a xenobiotic-free and human donor material-free system using a similar scaffold, if given the appropriate combination of growth factors and small molecules. ${ }^{197,198}$ Hence, engineering Wnt activator compounds is a crucial step toward generating a cocktail of necessary niche factors for an optimal in vitro SC expansion.

Finally, most Wnt activators are still at their early stages of development. Their safety and efficacy profiles need to be confirmed, as well as their optimal delivery mode. Minimizing the systemic exposure to Wnt activators and preventing off-target effects are crucial end-points that remain to be deciphered. The local use of Wnt activators could minimize these risks, and have been described in cutaneous injuries and cardiac infarction, where scaffolds loaded with Wnt agonists are placed 
directly on the site of injury. ${ }^{199}$ Wnt agonists can also be successfully used to promote SC expansion in vivo and are perfect applications of ex vivo limbal SC expansion and corneal wound healing (Table 1). ${ }^{14}$

\section{Conclusion}

The ability to activate Wnt pathways offers numerous promises. However, challenges to engineer highly selective targets capable of activating the Wnt/ $\beta$-catenin pathway without perturbing other signaling pathways, and in a cell-type specific manner, are ongoing. Fine-tuning of Wnt agonist therapies is necessary for the optimization of their clinical efficacy and safety for SC therapy and regenerative medicine.

\section{Author contributions}

$\mathrm{CB}, \mathrm{AB}$ : literature review and manuscript draft; SXD and JJZ: manuscript design, revisions, and final approval.

\section{Conflicts of interest}

Supported by the National Eye Institute (R01EY021797, R01EY028557, and 5P30EY000331), California Institute for Regenerative Medicine (TR2-01768, BF1-01768) and an unrestricted grant from Research to Prevent Blindness. SXD is a consultant for Dompe US. $\mathrm{CB}, \mathrm{AB}$, and JJZ declare no conflict of interests.

\section{Acknowledgements}

We thank the members of Deng and Zheng laboratories for many helpful discussions.

\section{Notes and references}

1 S. Yamamoto, K. L. Schulze and H. J. Bellen, Methods Mol. Biol., 2014, 1187, 1-14.

2 F. Wu, Y. Zhang, B. Sun, A. P. McMahon and Y. Wang, Cell Chem. Biol., 2017, 24, 252-280.

3 A. Hata and Y. G. Chen, Cold Spring Harbor Perspect. Biol., 2016, 8, a022061.

4 Z. Meng, T. Moroishi and K. L. Guan, Genes Dev., 2016, 30, 1-17.

5 R. Nusse, C. Fuerer, W. Ching, K. Harnish, C. Logan, A. Zeng, D. ten Berge and Y. Kalani, Cold Spring Harbor Symp. Quant. Biol., 2008, 73, 59-66.

6 H. Clevers and R. Nusse, Cell, 2012, 149, 1192-1205.

7 E. R. Wagner, G. Zhu, B. Q. Zhang, Q. Luo, Q. Shi, E. Huang, Y. Gao, J. L. Gao, S. H. Kim, F. Rastegar, K. Yang, B. C. He, L. Chen, G. W. Zuo, Y. Bi, Y. Su, J. Luo, X. Luo, J. Huang, Z. L. Deng, R. R. Reid, H. H. Luu, R. C. Haydon and T. C. He, Curr. Mol. Pharmacol., 2011, 4, 14-25.
8 L. Yin, C. Niu, L. X. Liao, J. Dou, M. Habasi and H. A. Aisa, Molecules, 2017, 22, 2077.

9 N. C. Inestrosa and E. M. Toledo, Mol. Neurodegener., 2008, $3,9$.

10 M. Katoh and M. Katoh, Clin. Cancer Res., 2007, 13, 4042-4045.

11 M. Katoh and M. Katoh, Int. J. Mol. Med., 2017, 40, 587-606.

12 A. Blagodatski, A. Klimenko, L. Jia and V. L. Katanaev, Cells, 2020, 9(3), 589.

13 F. H. Tran and J. J. Zheng, Protein Sci., 2017, 26, 650-661.

14 C. Zhang, H. Mei, S. Y. T. Robertson, H. J. Lee, S. X. Deng and J. J. Zheng, iScience, 2020, 23, 101075.

15 C. M. Cruciat and C. Niehrs, Cold Spring Harbor Perspect. Biol., 2013, 5, a015081.

16 R. Nusse and H. Clevers, Cell, 2017, 169, 985-999.

17 Z. F. Zimmerman, R. T. Moon and A. J. Chien, Cold Spring Harbor Perspect. Biol., 2012, 4(11), a008086.

18 R. Nusse and H. E. Varmus, Cell, 1992, 69, 1073-1087.

19 K. Willert and R. Nusse, Cold Spring Harbor Perspect. Biol., 2012, 4, a007864.

20 K. E. Wiese, R. Nusse and R. van Amerongen, Development, 2018, 145(12), dev165902.

21 M. Katoh, Int. J. Oncol., 2017, 51, 1357-1369.

22 C. Bonnet, S. Gonzalez, J. S. Roberts, S. Robertson, M. Ruiz, J. Zheng and S. X. Deng, Prog. Retinal Eye Res., 2021, 100956, DOI: 10.1016/j.preteyeres.2021.100956.

23 H. Clevers, K. M. Loh and R. Nusse, Science, 2014, 346, 1248012.

24 M. D. Gordon and R. Nusse, J. Biol. Chem., 2006, 281, 22429-22433.

25 C. Y. Logan and R. Nusse, Annu. Rev. Cell Dev. Biol., 2004, 20, 781-810.

26 J. L. Green, M. Bauer, K. W. Yum, Y. C. Li, M. L. Cox, K. Willert and G. M. Wahl, PLoS One, 2013, 8, e58395.

27 L. Hinze, M. Pfirrmann, S. Karim, J. Degar, C. McGuckin, D. Vinjamur, J. Sacher, K. E. Stevenson, D. S. Neuberg, E. Orellana, M. Stanulla, R. I. Gregory, D. E. Bauer, F. F. Wagner, K. Stegmaier and A. Gutierrez, Cancer Cell, 2019, 35, 664-676.

28 C. Fuerer and R. Nusse, PLoS One, 2010, 5(2), e9370.

29 K. Willert, J. D. Brown, E. Danenberg, A. W. Duncan, I. L. Weissman, T. Reya, J. R. Yates, 3rd and R. Nusse, Nature, 2003, 423, 448-452.

30 A. J. Mikels and R. Nusse, PLoS Biol., 2006, 4, e115.

31 J. von Maltzahn, R. Zinoviev, N. C. Chang, C. F. Bentzinger and M. A. Rudnicki, Nat. Commun., 2013, 4, 2869.

32 J. P. Dijksterhuis, B. Baljinnyam, K. Stanger, H. O. Sercan, Y. Ji, O. Andres, J. S. Rubin, R. N. Hannoush and G. Schulte, J. Biol. Chem., 2015, 290, 6789-6798.

33 X. He, J. P. Saint-Jeannet, Y. Wang, J. Nathans, I. Dawid and H. Varmus, Science, 1997, 275, 1652-1654.

34 H. Chen, C. Lu, B. Ouyang, H. Zhang, Z. Huang, D. Bhatia, S. J. Lee, D. Shah, A. Sura, W. C. Yeh and Y. Li, Cell. Chem. Biol., 2020, 27, 598-609.

35 C. Y. Janda, L. T. Dang, C. You, J. Chang, W. de Lau, Z. A. Zhong, K. S. Yan, O. Marecic, D. Siepe, X. Li, 
J. D. Moody, B. O. Williams, H. Clevers, J. Piehler, D. Baker, C. J. Kuo and K. C. Garcia, Nature, 2017, 545, 234-237.

36 Y. Tao, M. Mis, L. Blazer, M. J. Ustav, Z. Steinhart, R. Chidiac, E. Kubarakos, S. O’Brien, X. Wang, N. Jarvik, N. Patel, J. Adams, J. Moffat, S. Angers and S. S. Sidhu, eLife, 2019, 8, e46134.

37 G. Pellegrini, P. Rama, S. Matuska, A. Lambiase, S. Bonini,

A. Pocobelli, R. G. Colabelli, L. Spadea, R. Fasciani,

E. Balestrazzi, P. Vinciguerra, P. Rosetta, A. Tortori, M. Nardi, G. Gabbriellini, C. E. Traverso, C. Macaluso, L. Losi, A. Percesepe, B. Venturi, F. Corradini, A. Panaras, A. Di Rocco, P. Guatelli and M. De Luca, Regener. Med., 2013, 8, 553-567.

38 Z. Pavlovic, J. Adams, L. Blazer, A. Gakhal, N. Jarvik, Z. Steinhart, M. Robitaille, K. Mascall, J. Pan, S. Angers, J. Moffat and S. Sidhu, mAbs, 2018, 10, 1157-1167.

39 Y. Miao, A. Ha, W. de Lau, K. Yuki, A. J. M. Santos, C. You, M. H. Geurts, J. Puschhof, C. Pleguezuelos-Manzano, W. C. Peng, R. Senlice, C. Piani, J. W. Buikema, O. M. Gbenedio, M. Vallon, J. Yuan, S. de Haan, W. Hemrika, K. Rösch, L. T. Dang, D. Baker, M. Ott, P. Depeille, S. M. Wu, J. Drost, R. Nusse, J. P. Roose, J. Piehler, S. F. Boj, C. Y. Janda, H. Clevers, C. J. Kuo and K. C. Garcia, Cell Stem Cell, 2020, 27, 840-851.e846.

40 W. M. Blankesteijn, H. Laeremans and T. M. Hackeng, EP2403516, 2010.

41 M. Rotherham and A. J. El Haj, PLoS One, 2015, 10, e0121761.

42 M. Rotherham, J. R. Henstock, O. Qutachi and A. J. El Haj, Nanomedicine, 2018, 14, 173-184.

43 M. Rotherham, T. Nahar, T. Goodman, N. Telling, M. Gates and A. El Haj, Adv. Biosyst., 2019, 3, e1900091.

44 J. Ke, K. G. Harikumar, C. Erice, C. Chen, X. Gu, L. Wang, N. Parker, Z. Cheng, W. Xu, B. O. Williams, K. Melcher, L. J. Miller and H. E. Xu, Genes Dev., 2013, 27, 2305-2319.

45 W. A. Dailey, K. A. Drenser, S. C. Wong, M. Cheng, J. Vercellone, K. K. Roumayah, E. V. Feeney, M. Deshpande, A. E. Guzman, M. Trese and K. P. Mitton, Exp. Eye Res., 2017, 164, 129-138.

46 M. Díaz-Coránguez, C. M. Lin, S. Liebner and D. A. Antonetti, J. Biol. Chem., 2020, 295, 4647-4660.

47 Q. Xu, Y. Wang, A. Dabdoub, P. M. Smallwood, J. Williams, C. Woods, M. W. Kelley, L. Jiang, W. Tasman, K. Zhang and J. Nathans, Cell, 2004, 116, 883-895.

48 A. Ohlmann and E. R. Tamm, Prog. Retinal Eye Res., 2012, 31, 243-257.

49 R. Baron and M. Kneissel, Nat. Med., 2013, 19, 179-192.

50 E. Tian, F. Zhan, R. Walker, E. Rasmussen, Y. Ma, B. Barlogie and J. D. Shaughnessy, Jr., N. Engl. J. Med., 2003, 349, 2483-2494.

51 N. Voorzanger-Rousselot, D. Goehrig, F. Journe, V. Doriath, J. J. Body, P. Clézardin and P. Garnero, Br. J. Cancer, 2007, 97, 964-970.

52 A. Caricasole, A. Copani, F. Caraci, E. Aronica, A. J. Rozemuller, A. Caruso, M. Storto, G. Gaviraghi, G. C. Terstappen and F. Nicoletti, J. Neurosci., 2004, 24, 6021-6027.
53 I. Cappuccio, A. Calderone, C. L. Busceti, F. Biagioni, F. Pontarelli, V. Bruno, M. Storto, G. T. Terstappen, G. Gaviraghi, F. Fornai, G. Battaglia, D. Melchiorri, R. S. Zukin, F. Nicoletti and A. Caricasole, J. Neurosci., 2005, 25, 2647-2657.

54 S. Negri, Y. Wang, T. Sono, Q. Qin, G. C. Hsu, M. Cherief, J. Xu, S. Lee, R. J. Tower, V. Yu, A. Piplani, C. A. Meyers, K. Broderick, M. Lee and A. W. James, Stem Cells Transl. Med., 2021, 10, 610-622.

55 X. Li, M. Grisanti, W. Fan, F. J. Asuncion, H. L. Tan, D. Dwyer, C. Y. Han, L. Yu, J. Lee, E. Lee, M. Barrero, P. Kurimoto, Q. T. Niu, Z. Geng, A. Winters, T. Horan, S. Steavenson, F. Jacobsen, Q. Chen, R. Haldankar, J. Lavallee, B. Tipton, M. Daris, J. Sheng, H. S. Lu, K. Daris, R. Deshpande, E. G. Valente, H. Salimi-Moosavi, P. J. Kostenuik, J. Li, M. Liu, C. Li, D. L. Lacey, W. S. Simonet, H. Z. Ke, P. Babij, M. Stolina, M. S. Ominsky and W. G. Richards, J. Bone Miner. Res., 2011, 26, 2610-2621.

56 J. Bao, J. J. Zheng and D. Wu, Sci. Signaling, 2012, 5, pe22.

57 H. Jin, B. Wang, J. Li, W. Xie, Q. Mao, S. Li, F. Dong, Y. Sun, H. Z. Ke, P. Babij, P. Tong and D. Chen, Bone, 2015, 71, 63-75.

58 Y. Wang, S. Negri, Z. Li, J. Xu, C. Y. Hsu, B. Peault, K. Broderick and A. W. James, Stem Cells Dev., 2020, 29, 1007-1015.

59 M. Fulciniti, P. Tassone, T. Hideshima, S. Vallet, P. Nanjappa, S. A. Ettenberg, Z. Shen, N. Patel, Y. T. Tai, D. Chauhan, C. Mitsiades, R. Prabhala, N. Raje, K. C. Anderson, D. R. Stover and N. C. Munshi, Blood, 2009, 114, 371-379.

60 J. C. Bendell, J. E. Murphy, D. Mahalingam, B. Halmos, C. A. Sirard, S. B. Landau and D. P. Ryan, J. Clin. Oncol., 2016, 34, 111.

61 A. M. Betts, T. H. Clark, J. Yang, J. L. Treadway, M. Li, M. A. Giovanelli, Y. Abdiche, D. M. Stone and V. M. Paralkar, J. Pharmacol. Exp. Ther., 2010, 333, 2-13.

62 L. D’Amico, S. Mahajan, A. H. Capietto, Z. Yang, A. Zamani, B. Ricci, D. B. Bumpass, M. Meyer, X. Su, A. Wang-Gillam, K. Weilbaecher, S. A. Stewart, D. G. DeNardo and R. Faccio, J. Exp. Med., 2016, 213, 827-840.

63 X. Li, J. Shan, W. Chang, I. Kim, J. Bao, H. J. Lee, X. Zhang, V. T. Samuel, G. I. Shulman, D. Liu, J. J. Zheng and D. Wu, Proc. Natl. Acad. Sci. U. S. A., 2012, 109, 11402-11407.

64 M. R. McClung, A. Grauer, S. Boonen, M. A. Bolognese, J. P. Brown, A. Diez-Perez, B. L. Langdahl, J. Y. Reginster, J. R. Zanchetta, S. M. Wasserman, L. Katz, J. Maddox, Y. C. Yang, C. Libanati and H. G. Bone, N. Engl. J. Med., 2014, 370, 412-420.

65 A. Roschger, P. Roschger, P. Keplingter, K. Klaushofer, S. Abdullah, M. Kneissel and F. Rauch, Bone, 2014, 66, 182-188.

66 R. R. Recker, C. T. Benson, T. Matsumoto, M. A. Bolognese, D. A. Robins, J. Alam, A. Y. Chiang, L. Hu, J. H. Krege, H. Sowa, B. H. Mitlak and S. L. Myers, J. Bone Miner. Res., 2015, 30, 216-224. 
67 Z. Cheng, T. Biechele, Z. Wei, S. Morrone, R. T. Moon, L. Wang and W. Xu, Nat. Struct. Mol. Biol., 2011, 18, 1204-1210.

68 M. Florio, K. Gunasekaran, M. Stolina, X. Li, L. Liu, B. Tipton, H. Salimi-Moosavi, F. J. Asuncion, C. Li, B. Sun, H. L. Tan, L. Zhang, C. Y. Han, R. Case, A. N. Duguay, M. Grisanti, J. Stevens, J. K. Pretorius, E. Pacheco, H. Jones, Q. Chen, B. D. Soriano, J. Wen, B. Heron, F. W. Jacobsen, E. Brisan, W. G. Richards, H. Z. Ke and M. S. Ominsky, Nat. Commun., 2016, 7, 11505.

69 O. Kazanskaya, A. Glinka, I. del Barco Barrantes, P. Stannek, C. Niehrs and W. Wu, Dev. Cell, 2004, 7, 525-534.

70 J. K. Yoon and J. S. Lee, Cell Signaling, 2012, 24, 369-377. 71 K. A. Kim, M. Wagle, K. Tran, X. Zhan, M. A. Dixon, S. Liu, D. Gros, W. Korver, S. Yonkovich, N. Tomasevic, M. Binnerts and A. Abo, Mol. Biol. Cell, 2008, 19, 2588-2596.

72 A. Glinka, C. Dolde, N. Kirsch, Y. L. Huang, O. Kazanskaya, D. Ingelfinger, M. Boutros, C. M. Cruciat and C. Niehrs, EMBO Rep., 2011, 12, 1055-1061.

73 K. S. Carmon, X. Gong, Q. Lin, A. Thomas and Q. Liu, Proc. Natl. Acad. Sci. U. S. A., 2011, 108, 11452-11457.

74 W. de Lau, N. Barker, T. Y. Low, B. K. Koo, V. S. Li, H. Teunissen, P. Kujala, A. Haegebarth, P. J. Peters, M. van de Wetering, D. E. Stange, J. E. van Es, D. Guardavaccaro, R. B. Schasfoort, Y. Mohri, K. Nishimori, S. Mohammed, A. J. Heck and H. Clevers, Nature, 2011, 476, 293-297.

75 H. Hao, Y. Xie, Y. Zhang, O. Charlat, E. Oster, M. Avello, H. Lei, C. Mickanin, D. Liu, H. Ruffner, X. Mao, Q. Ma, R. Zamponi, T. Bouwmeester, P. Finan, M. Kirschner, J. Porter, F. Serluca and F. Cong, Nature, 2012, 485, 195-200.

76 B. K. Koo, M. Spit, I. Jordens, T. Y. Low, D. E. Stange, M. van de Wetering, J. H. van Es, S. Mohammed, A. J. Heck, M. M. Maurice and H. Clevers, Nature, 2012, 488, 665-669.

77 A. M. Lebensohn and R. Rohatgi, eLife, 2018, 7, e33126.

78 T. Sato, R. G. Vries, H. J. Snippert, M. van de Wetering, N. Barker, D. E. Stange, J. H. van Es, A. Abo, P. Kujala, P. J. Peters and H. Clevers, Nature, 2009, 459, 262-265.

79 W. J. Zhou, Z. H. Geng, J. R. Spence and J. G. Geng, Nature, 2013, 501, 107-111.

80 K. Yan, C. Janda, J. Chang, G. Zheng, K. Larkin, V. Luca, L. Chia, A. Mah, A. Han, J. Terry, A. Ootani, K. Roelf, M. Lee, J. Yuan, X. Li, C. Bolen, J. Wilhelmy, P. Davies, H. Ueno, R. von Furstenberg, P. Belgrader, S. Ziraldo, H. Ordonez, S. Henning, M. Wong, M. Snyder, I. Weissman, A. Hsueh, T. Mikkelsen, K. Garcia and C. Kuo, Nature, 2017, 545, 238-242.

81 M. J. Feldhaus, R. W. Siegel, L. K. Opresko, J. R. Coleman, J. M. Feldhaus, Y. A. Yeung, J. R. Cochran, P. Heinzelman, D. Colby, J. Swers, C. Graff, H. S. Wiley and K. D. Wittrup, Nat. Biotechnol., 2003, 21, 163-170.

82 V. Luca, Y. Miao, X. Li, M. Hollander, C. Kuo and K. Garcia, PLoS One, 2020, 15, e0226928.
83 Z. Zhang, C. Broderick, M. Nishimoto, T. Yamaguchi, S. J. Lee, H. Zhang, H. Chen, M. Patel, J. Ye, A. Ponce, J. Brady, H. Baribault, Y. Li and W. C. Yeh, Sci. Rep., 2020, 10, 13951.

84 W. Satoh, M. Matsuyama, H. Takemura, S. Aizawa and A. Shimono, Genesis, 2008, 46, 92-103.

85 T. Gaur, L. Rich, C. J. Lengner, S. Hussain, B. Trevant, D. Ayers, J. L. Stein, P. V. Bodine, B. S. Komm, G. S. Stein and J. B. Lian, J. Cell. Physiol., 2006, 208, 87-96.

86 P. Bodine, B. Stauffer, H. Ponce-de-Leon, R. Bhat, A. Mangine, L. Seestaller-Wehr, R. Moran, J. Billiard, S. Fukayama, B. Komm, K. Pitts, G. Krishnamurthy, A. Gopalsamy, M. Shi, J. Kern, T. Commons, R. Woodworth, M. Wilson, G. Welmaker, E. Trybulski and W. Moore, Bone, 2009, 44, 1063-1068.

87 A. Gopalsamy, M. Shi, B. Stauffer, R. Bahat, J. Billiard, H. Ponce-de-Leon, L. Seestaller-Wehr, S. Fukayama, A. Mangine, R. Moran, G. Krishnamurthy and P. Bodine, J. Med. Chem., 2008, 51, 7670-7672.

88 W. J. Moore, J. C. Kern, R. Bhat, T. J. Commons, S. Fukayama, I. Goljer, G. Krishnamurthy, R. L. Magolda, L. Nogle, K. Pitts, B. Stauffer, E. J. Trybulski, G. S. Welmaker, M. Wilson and P. V. Bodine, J. Med. Chem., 2009, 52, 105-116.

89 X. Zhang, S. M. Cheong, N. G. Amado, A. H. Reis, B. T. MacDonald, M. Zebisch, E. Y. Jones, J. G. Abreu and X. He, Dev. Cell, 2015, 32, 719-730.

90 J. E. Tarver, Jr., P. K. Pabba, J. Barbosa, Q. Han, M. W. Gardyan, R. Brommage, A. Y. Thompson, J. M. Schmidt, A. G. E. Wilson, W. He, V. K. Lombardo and K. G. Carson, Bioorg. Med. Chem. Lett., 2016, 26, 1525-1528.

91 R. Brommage, J. Liu, P. Vogel, F. Mseeh, A. Y. Thompson, D. G. Potter, M. K. Shadoan, G. M. Hansen, S. Jeter-Jones, J. Cui, D. Bright, J. P. Bardenhagen, D. D. Doree, S. Movérare-Skrtic, K. H. Nilsson, P. Henning, U. H. Lerner, C. Ohlsson, A. T. Sands, J. E. Tarver, D. R. Powell, B. Zambrowicz and Q. Liu, Bone Res., 2019, $7,2$.

92 R. M. Suciu, A. B. Cognetta, 3rd, Z. E. Potter and B. F. Cravatt, ACS Med. Chem. Lett., 2018, 9, 563-568.

93 B. N. Atkinson, D. Steadman, Y. Zhao, J. Sipthorp, L. Vecchia, R. R. Ruza, F. Jeganathan, G. Lines, S. Frew, A. Monaghan, S. Kjær, M. Bictash, E. Y. Jones and P. V. Fish, MedChemComm, 2019, 10, 1361-1369.

94 C. M. Hedgepeth, L. J. Conrad, J. Zhang, H. C. Huang, V. M. Lee and P. S. Klein, Dev. Biol., 1997, 185, 82-91.

95 L. Freland and J. M. Beaulieu, Front. Mol. Neurosci., 2012, $5,14$.

96 P. Rattanawarawipa, P. Pavasant, T. Osathanon and W. Sukarawan, Tissue Cell, 2016, 48, 425-431.

97 L. Qi, Y. Tang, W. He, H. Pan, W. Jiang, L. Wang and W. Deng, Cytotechnology, 2017, 69, 277-287.

98 C. Galli, M. Piemontese, S. Lumetti, E. Manfredi, G. M. Macaluso and G. Passeri, Clin. Oral. Implants Res., 2013, 24, 921-927. 
99 H. Eldar-Finkelman, S. A. Schreyer, M. M. Shinohara, R. C. LeBoeuf and E. G. Krebs, Diabetes, 1999, 48, 1662-1666.

100 S. Aiston, M. P. Coghlan and L. Agius, Eur. J. Biochem., 2003, 270, 2773-2781.

101 S. E. Nikoulina, T. P. Ciaraldi, S. Mudaliar, P. Mohideen, L. Carter and R. R. Henry, Diabetes, 2000, 49, 263-271.

102 L. Meijer, A. L. Skaltsounis, P. Magiatis, P. Polychronopoulos, M. Knockaert, M. Leost, X. P. Ryan, C. A. Vonica, A. Brivanlou, R. Dajani, C. Crovace, C. Tarricone, A. Musacchio, S. M. Roe, L. Pearl and P. Greengard, Chem. Biol., 2003, 10, 1255-1266.

103 N. Sato, L. Meijer, L. Skaltsounis, P. Greengard and A. H. Brivanlou, Nat. Med., 2004, 10, 55-63.

104 A. D. Sklirou, N. Gaboriaud-Kolar, I. Papassideri, A. L. Skaltsounis and I. P. Trougakos, Sci. Rep., 2017, 7, 11713.

105 T. Blažević, E. H. Heiss, A. G. Atanasov, J. M. Breuss, V. M. Dirsch and P. Uhrin, Evidence-Based Complementary Altern. Med., 2015, 2015, 654098.

106 G. Eisenbrand, F. Hippe, S. Jakobs and S. Muehlbeyer, J. Cancer Res. Clin. Oncol., 2004, 130, 627-635.

107 A. S. Tseng, F. B. Engel and M. T. Keating, Chem. Biol., 2006, 13, 957-963.

108 M. J. Moon, S. K. Lee, J. W. Lee, W. K. Song, S. W. Kim, J. I. Kim, C. Cho, S. J. Choi and Y. C. Kim, Bioorg. Med. Chem., 2006, 14, 237-246.

109 E. Park, S. Choi, Y. Kim, S. Lee, S. Park and S. Lee, Bioorg. Med. Chem. Lett., 2009, 19, 2282-2284.

110 S. Gonzalez, D. Oh, E. R. Baclagon, J. J. Zheng and S. X. Deng, Invest. Ophthalmol. Visual Sci., 2019, 60, 107-112.

111 A. M. Gilbert, M. G. Bursavich, N. Alon, B. M. Bhat, F. J. Bex, M. Cain, V. Coleburn, V. Gironda, P. Green, D. B. Hauze, Y. Kharode, G. Krishnamurthy, M. Kirisits, H. S. Lam, Y. B. Liu, S. Lombardi, J. Matteo, R. Murrills, J. A. Robinson, S. Selim, M. Sharp, R. Unwalla, U. Varadarajan, W. Zhao and P. J. Yaworsky, Bioorg. Med. Chem. Lett., 2010, 20, 366-370.

112 C. Tapia-Rojas, A. Schüller, C. B. Lindsay, R. C. Ureta, C. Mejías-Reyes, J. Hancke, F. Melo and N. C. Inestrosa, Biochem. J., 2015, 466, 415-430.

113 Y. Li, J. Xu, Y. Chen, Z. Mei and Y. Xiao, J. Chromatogr. A, 2015, 1425, 8-16.

114 S. Ding, T. Y. Wu, A. Brinker, E. C. Peters, W. Hur, N. S. Gray and P. G. Schultz, Proc. Natl. Acad. Sci. U. S. A., 2003, 100, 7632-7637.

115 T. Miyabayashi, J. L. Teo, M. Yamamoto, M. McMillan, C. Nguyen and M. Kahn, Proc. Natl. Acad. Sci. U. S. A., 2007, 104, 5668-5673.

116 M. P. Coghlan, A. E. Fenwick, D. Haigh, J. C. Holder, R. J. Ife, A. D. Reith, D. G. Smith and R. W. Ward, WO200021927-A2, 2000.

117 M. P. Coghlan, A. A. Culbert, D. A. Cross, S. L. Corcoran, J. W. Yates, N. J. Pearce, O. L. Rausch, G. J. Murphy, P. S. Carter, L. Roxbee Cox, D. Mills, M. J. Brown,
D. Haigh, R. W. Ward, D. G. Smith, K. J. Murray, A. D. Reith and J. C. Holder, Chem. Biol., 2000, 7, 793-803.

118 A. Takashima, K. Noguchi, K. Sato, T. Hoshino and K. Imahori, Proc. Natl. Acad. Sci. U. S. A., 1993, 90, 7789-7793.

119 K. Imahori, M. Hoshi, K. Ishiguro, K. Sato, M. Takahashi, R. Shiurba, H. Yamaguchi, A. Takashima and T. Uchida, Neurobiol. Aging, 1998, 19, S93-S98.

120 Y. Wu, Z. Ai, K. Yao, L. Cao, J. Du, X. Shi, Z. Guo and Y. Zhang, Exp. Cell Res., 2013, 319, 2684-2699.

121 M. Zhang, J. Shi, Y. Huang and L. Lai, BMC Dev. Biol., 2012, 12, 21.

122 B. Martin, B. Gabris, A. F. Barakat, B. L. Henry, M. Giannini, R. P. Reddy, X. Wang, G. Romero and G. Salama, Sci. Rep., 2019, 9, 18545.

123 Y. Yoshida, T. Soma, T. Matsuzaki and J. Kishimoto, Biochem. Biophys. Res. Commun., 2019, 516, 599-605.

124 X. Yin, H. F. Farin, J. H. van Es, H. Clevers, R. Langer and J. M. Karp, Nat. Methods, 2014, 11, 106-112.

125 C. Li, S. Zhang, Y. Lu, Y. Zhang, E. Wang and Z. Cui, PLoS One, 2013, 8, e84659.

126 K. W. McCracken, E. Aihara, B. Martin, C. M. Crawford, T. Broda, J. Treguier, X. Zhang, J. M. Shannon, M. H. Montrose and J. M. Wells, Nature, 2017, 541, 182-187.

127 A. Licht-Murava, R. Paz, L. Vaks, L. Avrahami, B. Plotkin, M. Eisenstein and H. Eldar-Finkelman, Sci. Signaling, 2016, 9, ra110.

128 T. L. Biechele, N. D. Camp, D. M. Fass, R. M. Kulikauskas, N. C. Robin, B. D. White, C. M. Taraska, E. C. Moore, J. Muster, R. Karmacharya, S. J. Haggarty, A. J. Chien and R. T. Moon, Chem. Biol., 2010, 17, 1177-1182.

129 J. M. Atkinson, K. B. Rank, Y. Zeng, A. Capen, V. Yadav, J. R. Manro, T. A. Engler and M. Chedid, PLoS One, 2015, 10, e0125028.

130 I. Rippin, N. Khazanov, J. Shirley Ben, T. Kudinov, E. Berent, S. M. Arciniegas Ruiz, D. Marciano, L. Levy, A. Gruzman, H. Senderowitz and H. Eldar-Finkelman, Int. J. Mol. Sci., 2020, 21, 8709.

131 E. Beurel, S. F. Grieco and R. S. Jope, Pharmacol. Ther., 2015, 148, 114-131.

132 P. Patel and J. R. Woodgett, Curr. Top. Dev. Biol., 2017, 123, 277-302.

133 B. W. Doble and J. R. Woodgett, J. Cell Sci., 2003, 116, 1175-1186.

134 P. Jeong, Y. Moon, J. H. Lee, S. D. Lee, J. Park, J. Lee, J. Kim, H. J. Lee, N. Y. Kim, J. Choi, J. D. Heo, J. E. Shin, H. W. Park, Y. G. Kim, S. Y. Han and Y. C. Kim, Eur. J. Med. Chem., 2020, 195, 112205.

135 S. Jiang, M. Zhang, J. Sun and X. Yang, Cell Commun. Signaling, 2018, 16, 23.

136 C. Liu, Y. Li, M. Semenov, C. Han, G. H. Baeg, Y. Tan, Z. Zhang, X. Lin and X. He, Cell, 2002, 108, 837-847.

137 A. Ferrarese, O. Marin, V. H. Bustos, A. Venerando, M. Antonelli, J. E. Allende and L. A. Pinna, Biochemistry, 2007, 46, 11902-11910. 
138 K. Ohishi, K. Toume, M. A. Arai, S. K. Sadhu, F. Ahmed, T. Mizoguchi, M. Itoh and M. Ishibashi, Bioorg. Med. Chem., 2014, 22, 4597-4601.

139 M. Kahn, Nat. Rev. Drug Discovery, 2014, 13, 513-532.

140 S. Basu, B. Ellinger, S. Rizzo, C. Deraeve, M. Schürmann, H. Preut, H. D. Arndt and H. Waldmann, Proc. Natl. Acad. Sci. U. S. A., 2011, 108, 6805-6810.

141 S. Barolo, Oncogene, 2006, 25, 7505-7511.

142 F. Fan and K. V. Wood, Assay Drug Dev. Technol., 2007, 5, 127-136.

143 J. Liu, X. Wu, B. Mitchell, C. Kintner, S. Ding and P. G. Schultz, Angew. Chem., Int. Ed., 2005, 44, 1987-1990.

144 M. Kuncewitch, W. L. Yang, E. Molmenti, J. Nicastro, G. F. Coppa and P. Wang, Shock, 2013, 39, 3-10.

145 Q. Zhang, M. B. Major, S. Takanashi, N. D. Camp, N. Nishiya, E. C. Peters, M. H. Ginsberg, X. Jian, P. A. Randazzo, P. G. Schultz, R. T. Moon and S. Ding, Proc. Natl. Acad. Sci. U. S. A., 2007, 104, 7444-7448.

146 J. Gwak, S. G. Hwang, H. S. Park, S. R. Choi, S. H. Park, H. Kim, N. C. Ha, S. J. Bae, J. K. Han, D. E. Kim, J. W. Cho and S. Oh, Cell Res., 2012, 22, 237-247.

147 M. Katoh, Oncol. Rep., 2005, 14, 1583-1588.

148 M. Park and R. T. Moon, Nat. Cell Biol., 2002, 4, 20-25.

149 H. V. Shaw, A. Koval and V. L. Katanaev, Methods Cell Biol., 2019, 149, 57-75.

150 H. J. Lee, J. Bao, A. Miller, C. Zhang, J. Wu, Y. C. Baday, C. Guibao, L. Li, D. Wu and J. J. Zheng, J. Biol. Chem., 2015, 290, 30596-30606.

151 M. H. Kim and K. S. Kang, Prev. Med., 2012, 54(Suppl), S57-S63.

152 H. Ji, K. Ahn, H. Cho, H. E. Kim, Y. Kim and O. Kim, Biochem. Biophys. Res. Commun., 2018, 504, 352-358.

153 J. F. Zhang, G. Li, C. Y. Chan, C. L. Meng, M. C. Lin, Y. C. Chen, M. L. He, P. C. Leung and H. F. Kung, Mol. Cell. Endocrinol., 2010, 314, 70-74.

154 P. H. Cha, W. Shin, M. Zahoor, H. Y. Kim, S. Min do and K. Y. Choi, PLoS One, 2014, 9, e85546.

155 T. Yodthong, U. Kedjarune-Leggat, C. Smythe, R. Wititsuwannakul and T. Pitakpornpreecha, Molecules, 2018, 23, 3086.

156 C. Liu, L. Wang, R. Zhu, H. Liu, R. Ma, B. Chen, L. Li, Y. Guo, Q. Jia, S. Shi, D. Zhao, F. Mo, B. Zhao, J. Niu, M. Fu, A. N. Orekhov, D. Brömme, S. Gao and D. Zhang, Osteoporosis Int., 2019, 30, 491-505.

157 H. Liu, R. Zhu, L. Wang, C. Liu, R. Ma, B. Qi, B. Chen, L. Li, Y. Guo, S. Shi, Q. Jia, J. Niu, D. Zhao, F. Mo, S. Gao and D. Zhang, Phytother. Res., 2018, 32, 2487-2500.

158 J. H. Hwang, P. H. Cha, G. Han, T. T. Bach, S. Min do and K. Y. Choi, Exp. Mol. Med., 2015, 47, e152.

159 M. B. Kim, Y. Song and J. K. Hwang, Fitoterapia, 2014, 98, 59-65.

160 K. Porwal, S. Pal, K. Dev, S. P. China, Y. Kumar, C. Singh, T. Barbhuyan, N. Sinha, S. Sanyal, A. K. Trivedi, R. Maurya and N. Chattopadhyay, J. Nutr. Biochem., 2017, 44, 22-34.

161 H. Gu, K. Boonanantanasarn, M. Kang, I. Kim, K. M. Woo, H. M. Ryoo and J. H. Baek, J. Med. Food, 2018, 21, 57-69.
162 J. W. Lee, M. Asai, S. K. Jeon, T. Iimura, T. Yonezawa, B. Y. Cha, J. T. Woo and A. Yamaguchi, Mol. Nutr. Food Res., 2015, 59, 386-400.

163 M. Liu, Y. Li and S. T. Yang, Stem Cells Dev., 2014, 23, 146-154.

164 H. Li, X. Li, G. Liu, J. Chen, X. Weng, F. Liu, H. Xu, X. Liu and H. Ye, Int. J. Mol. Med., 2013, 32, 1329-1336.

165 Y. Xing, Y. Zhang, L. Jia and X. Xu, Mol. Oral Microbiol., 2019, 34, 1-13.

166 Q. Gu, C. Chen, Z. Zhang, Z. Wu, X. Fan, Z. Zhang, W. Di and L. Shi, Pharmacol. Res., 2015, 97, 70-78.

167 M. Liu, J. Guo, J. Wang, L. Zhang, T. Pang and H. Liao, Cell. Mol. Neurobiol., 2014, 34, 913-923.

168 B. Zhu, F. Xue, C. Zhang and G. Li, J. Cell. Mol. Med., 2019, 23, 5782-5793.

169 P. J. Park, B. S. Moon, S. H. Lee, S. N. Kim, A. R. Kim, H. J. Kim, W. S. Park, K. Y. Choi, E. G. Cho and T. R. Lee, Life Sci., 2012, 91, 935-943.

170 A. Vallée, Y. Lecarpentier, R. Guillevin and J. N. Vallée, Acta Biochim. Biophys. Sin., 2017, 49, 853-866.

171 N. C. Robin, Z. Agoston, T. L. Biechele, R. G. James, J. D. Berndt and R. T. Moon, Stem Cell Rep., 2014, 2, 9-17.

172 S. K. Tiwari, S. Agarwal, B. Seth, A. Yadav, S. Nair, P. Bhatnagar, M. Karmakar, M. Kumari, L. K. Chauhan, D. K. Patel, V. Srivastava, D. Singh, S. K. Gupta, A. Tripathi, R. K. Chaturvedi and K. C. Gupta, ACS Nano, 2014, 8, 76-103.

173 A. Blagodatski, V. Cherepanov, A. Koval, V. I. Kharlamenko, Y. S. Khotimchenko and V. L. Katanaev, Sci. Rep., 2017, 7, 11964.

174 I. M. N. Molagoda, W. Karunarathne, Y. H. Choi, E. K. Park, Y. J. Jeon, B. J. Lee, C. H. Kang and G. Y. Kim, Biomolecules, 2019, 9, 711.

175 H. Go, H. J. Hwang and T. J. Nam, Mar. Biotechnol., 2011, 13, 433-440.

176 S. H. Song, I. H. Kim and T. J. Nam, Int. J. Mol. Med., 2012, 29, 741-746.

177 N. Chung, S. Marine, E. A. Smith, R. Liehr, S. T. Smith, L. Locco, E. Hudak, A. Kreamer, A. Rush, B. Roberts, M. B. Major, R. T. Moon, W. Arthur, M. Cleary, B. Strulovici and M. Ferrer, Assay Drug Dev. Technol., 2010, 8, 286-294.

178 K. H. Emami, C. Nguyen, H. Ma, D. H. Kim, K. W. Jeong, M. Eguchi, R. T. Moon, J. L. Teo, H. Y. Kim, S. H. Moon, J. R. Ha and M. Kahn, Proc. Natl. Acad. Sci. U. S. A., 2004, 101, 12682-12687.

179 M. Lepourcelet, Y. N. Chen, D. S. France, H. Wang, P. Crews, F. Petersen, C. Bruseo, A. W. Wood and R. A. Shivdasani, Cancer Cell, 2004, 5, 91-102.

180 R. van Amerongen, A. Mikels and R. Nusse, Sci. Signaling, 2008, 1, re9.

181 I. Ackers and R. Malgor, Diab. Vasc. Dis. Res., 2018, 15, 3-13. 182 A. Mcnairn and G. Guasch, Eur. J. Dermatol., 2011, 21(Suppl 2), 21-28.

183 M. Davanger and A. Evensen, Nature, 1971, 229, 560-561.

184 S. W. Lane, D. A. Williams and F. M. Watt, Nat. Biotechnol., 2014, 32, 795-803. 
185 D. Scadden, Nature, 2006, 441, 1075-1079.

186 D. Scadden, Cell, 2014, 157, 41-50.

187 R. Pai, A. Tarnawski and T. Tran, Mol. Biol. Cell, 2004, 15, 2156-2163.

188 T. Zhan, N. Rindtorff and M. Boutros, Oncogene, 2017, 36, 1461-1473.

189 G. J. Todaro and H. Green, J. Cell Biol., 1963, 17, 299-313.

190 J. G. Rheinwald and H. Green, Cell, 1975, 6, 331-343.

191 H. Green, O. Kehinde and J. Thomas, Proc. Natl. Acad. Sci. U. S. A., 1979, 76, 5665-5668.

192 N. E. O'Connor, J. B. Mulliken, S. Banks-Schlegel, O. Kehinde and H. Green, Lancet, 1981, 1, 75-78.

193 M. De Luca, G. Pellegrini and H. Green, Regener. Med., 2006, 1, 45-57.
194 C. Bonnet, J. S. Roberts and S. X. Deng, Exp. Eye Res., 2021, 108437, DOI: 10.1016/j.exer.2021.108437.

195 K. N. Nguyen, S. Bobba, A. Richardson, M. Park, S. L. Watson, D. Wakefield and N. Di, Girolamo, Acta Biomater., 2018, 65, 21-35.

196 R. E. Hynds, P. Bonfanti and S. M. Janes, EMBO Mol. Med., 2018, 10, 139-150.

197 M. Haagdorens, V. Cejpla, E. Melsbach, L. Koivusalo, H. Skottman, M. Griffith, R. Valiokas, N. Zakaria, I. Pintelon and M. J. Tassignon, Stem Cells Int., 2019, 2019, 7867613.

198 M. Yazdani, A. Shahdadfar, C. J. Jackson and T. P. Utheim, Cells, 2019, 8, 245.

199 N. E. S. Sibinga and D. F. Riascos-Bernal, WO2015073274A1, 2014. 